\title{
THE PREDICTIVE VALUE OF CEREBROSPINAL FLUID TAP-TEST IN NORMAL PRESSURE HYDROCEPHALUS
}

\author{
BENITO P. DAMASCENO*, EDMUR F. CARELLI**, DONIZETI C. HONORATO**, JOSE J. FACURE**
}

\begin{abstract}
Eighteen patients (mean age of 66.5 years) with normal pressure hydrocephalus (NPH) underwent a ventriculo-peritoneal shunt surgery. Prior to operation a cerebrospinal fluid tap-test (CSF-TT) was performed with measurements of gait pattern and psychometric functions (memory, visuo-motor speed and visuo-constructive skills) before and after the removal of $50 \mathrm{ml}$ CSF by lumbar puncture (LP). Fifteen patients improved and 3 were unchanged after surgery. Short duration of disease, gait disturbance preceding mental deterioration, wide temporal horns and sinall sulci on CT-scan were associated with good outcome after shunting. There was a good correlation between the results of CSF-TT and shunt surgery $\left(X^{2}=4.11, p h i=0.48, p<0.05\right)$, with gait test showing highest correlation ( $\mathrm{r}$ $=0.99, p=0.01$ ). In conclusion, this version of CSF-TT proved to be an effective test to predict improvement after shunting in patients with NPH.
\end{abstract}

KEY WORDS: normal pressure hydrocephalus, lumbar puncture, shunt surgery.

\section{Valor preditivo da punçāo liquórica ("tap test”) na hidroccfalia de pressão normal}

RESUMO - Este estudo visa melhorar o valor diagnóstico e preditivo da punçño liquórica ("tap test", TT) na hidrocefalia de pressão normal (HPN), particularmente nos casos cm que os dados clinicos e de neuroimagem são inconclusivos e não pernitem uma decisão cirúrgica segura. Dezoito pacientes (média de idade $=66.5$ anos) com HPN foram submetidos a derivação ("shunt") ventriculo-peritoneal. O TT era realizado antes da cirurgia, consistindo na análise quantitativa da marcha e funções cognitivas (memória, rapidez perceptivo-motora e habilidade vísuoconstrutiva) antes è depois da retirada de $50 \mathrm{ml}$ de liquor via punção lombar. Quinze pacientes melhoraram e 3 permaneceram inalterados após a cirurgia. Curta duração da doença, distúrbio da marcha précedendo a deterioração mental, dilatação dos conos temporais e apagamento (ou redução) dos sulcos corticais na tomografia computadoiizada cerebral estavam associados a bons resultados pós-operatórios. Houve boa correlação entre os resultados do TT e os do "shunt" $\left(X^{2}=4.11, p / h i=0.48, p<0.05\right)$, principalmente no teste da marcha $(r=0.99, p=0.01)$. Esta versão do TT liquórico mostrou-se efetiva na predição da melhora pós-operatória em pacientes com HPN.

PALAVRAS-CHAVE: hidrocefalia de pressão normal, punção lombar, cir'urgia de "shunt".

Normal pressure hydrocephalus (NPH) is characterized by gait disturbance, progressive mental deterioration and urinary incontinence associated with enlargement of the ventricular system and normal cerebrospinal fluid (CSF) pressure. In typical cases, gait disturbance is the first and most salient sign, followed by forgetfullness or mild dementia, psychomotor retardation, apathy (with parkinsonian or depressive appearance) and, later on, urinary urgency or incontinence. These cases present minor diagnostic difficulties and they are the most likely to improve after shunting ${ }^{\mathrm{K} .11 .13}$. Differential diagnostic problems may, however, arise in some patients with atypical or incomplete

Unidade de Neuropsicologia e Neurolinguistica* e Disciplina de Neurocirurgia**, Departamento de Neurologia, Faculdade de Ciências Médicas (FCM), Universidade Estadual de Campinas (UNICAMP). Aceite: 5dezembro-1997.

Dr. Benito P. Damasceno - Departamento de Neurologia FCM/UNICAMP - Caixa Postal 6111 - 13083-970 Campinas, SP - Brasil. 
clinical manifestations, as well as in patients with "subcortical" dementia (subcortical arteriosclerotic encephalopathy or Binswanger's disease, progressive supranuclear palsy, Parkinson's disease), which can mimic the clinical picture of NPH. Subcortical arteriosclerotic encephalopathy is, in fact, much more common than NPH and should be included in the differential diagnosis as the most probable cause of the "classical" triad"s. The results of computerized tomography (CT), magnetic resonance imaging (MRI) or radionuclide cisternography (RC) can be inconclusive and insufficient to establish a correct diagnosis and particularly to predict which patients will improve after shunt surgery. A "positive" RC (with ventricular reflux and convexity block) is not specific for NPH and can be seen in other dementia disorders and even in healthy subjects ${ }^{2}$. RC's predictive value has been repeatedly questioned, so that Vanneste et al..$^{21}$ suggested it should no longer be performed, as it will not reduce the diagnostic uncertainty remaining after clinical and CT evaluation. Even MRI (with CSF voiding sign in the aqueduct) has been criticized for its doubtful additional predictive value, besides its limited availability and high $\operatorname{costs}{ }^{14}$. All these limitations have stimulated the search for more accurate methods and criteria for selection of patients for shunt surgery, which can benefit $25-80 \%$ of these patients but has complication rates $(35-52 \%)$ that dissuade us from shunting every case with suspicion of $\mathrm{NPH}^{11,13}$. Thus, Adams et al. ${ }^{1}$ and Fisher ${ }^{7}$ originally described the beneficial (though transient) effect of CSF removal in patients with hydrocephalic dementia, as well as the improvement of these patients after shunt surgery. This method was later improved by Wikkelso et al. ${ }^{23.24}$ by introducing the quantitative testing of gait and cognitive functions before and after the drainage of 40-50 ml lumbar CSF (CSF tap test, henceforth called TT). Wikkelso et al. found that this test can predict not only the outcome of surgery but also the degree of improvement. Lately, however, this test has been criticized for its high rate of false negatives, which has led some authors ${ }^{4,6}$ to introduce the 5 days continuous external lumbar drainage in an attempt to improve the test's predictive value.

The aim of this study was to evaluate the predictive value of a modified version of Wikkclso's TT, with adaptations suited to test even illiterate subjects.

\section{MATERIAL AND METHODS}

Thirty-one patients with cognitive deterioration and enlarged ventricles were admitted to the Department of Neurology on suspicion of NPH. Eighteen of them (12 men and 6 women) were finally diagnosed as NPH and underwent a ventriculo-peritoneal shunt surgery with a medium-pressure valve. The remaining 13 patients ( 11 men and 2 women) had other types of dementia (Table) and were taken in this study as disease controls. NPH patients had mean age of 66.5 years (SD 9.6), average educational level of 2.1 years (SD 1.6), median duration of illness of 12 months, mean ventricular (frontal horns) index of 0.41 (SD 0.06; range 0.34 - 0.59) and mean score on Mini-Mental State Examination (MMSE) of 11.5 points (SD 4.3).

Every patient underwent the following evaluations: neurologic examination and careful history (obtained from both the patient and a relative); CT; electroencephalography; CSF analysis and relevant haematological, biochenical, bacteriological and immunological tests (for syphilis, toxoplasmosis and cysticercosis); MMSE" (adapted by Bertolucci et al.) ; Christensen's $s^{5}$ comprehensive test-battery ("Luria's Neuropsychological Investigation"); and, at last, TT. We used ICD-10 criteria ${ }^{22}$ for the diagnosis of dementia, which was graded by means of Reisberg's ${ }^{15}$ Global Deterioration Scale. NINCDS-ADRDA criteria ${ }^{14}$ werc used for the diagnosis of probable and possible Alzheimer's disease.

The diagnosis of NPH was based on the following criteria: 1) a history of gait disturbance, progressive mental deterioration, and urinary urgency or incontinence; 2) hydrocephalus, defined as Evans' ratio (the ratio between the maximal width of the frontal horns and the internal diameter of the skull at the same level) above 0.30 on $\mathrm{CT}$; 3) a mean CSF pressure below $18 \mathrm{~cm}$ of water.

TT was performed on all 31 patients on two consecutive days and at the same hour each day. On the morning of the first day the patients underwent evaluation of gait and cognitive functions. On the second day these evaluations were repeated, 2 and 8 hours after a lumbar puncture (LP) with removal of $50 \mathrm{ml} \mathrm{CSF}$. The best score obtained by the paticnt in cach subtest at these two post-LP evaluations was his post-LP score. Postsurgical follow-up examination 
(with psychometric tests and gait analysis) was performed at 3 and 6 months, at 1 year, and thereafter every year. CT was regularly repeated at the 6 th month follow-np. If the patient did not improve, we examined the shunt function by percutaneously testing the proximal and distal patency of the shunt (and the valve function), as well as by analysing changes in ventricular size on CT scan. TT test-battery took about 30 minutes to be administered and comprised following subtests:

A. Gait examinatiom. The examiner counted the number of steps and the time spent by the patient for walking $18 \mathrm{~m}$ as quickly as possible. The mean value of four attempts was the patient's score.

B. Test of visure-motor speed (Cylinders test $)^{10}$. The test consists of 2 wooden plates with 60 holes in cach plate. In one plate, the holes are filled with easily graspable cylinders. The task was to move (with the dominant hand) the cylinders from one plate to another as fast as possible. The time needed to place all cylinders was measured, taking the average of three attempts.

C. Visuo-tonstructive skills. (1) To copy (with nine matches) two pentagons bound by one of their sides (score 1 if this was correctly copied). (2) Kohs test: to reproduce stimulus designs with four multicolored cubes. The four test items of Figure 7- I I of Strub \& Black ${ }^{17}$ were used. A score of 1 was given for cach correctly reproduced design. Rotations (either right-left or near-far) as well as figure-ground (color) reversals were scored as incorrect. The maximum score of test $C$ was 5 points.

D. Memory. (1) Tactile-verbal memory: The subject had to recall orally or by tactile multiple choice four objects recognized by touch (and eventually named) three minutes earlier (button and match in the right hand; coin and nail in the left hand). One point was given for each correctly recalled object. If the subject was unable to recognize these objects (due to paresis or astcreognosis), he/she was allowed to see (and name) them. (2) Visuli inemory: The subject was shown a relatively nonverbalizable drawing for 10 seconds and asked to choose the correct one from among four others after a three-minutes ocupied pause [test items of Figure 1 of Ross ${ }^{15}$ were used]. Four different stimulus items were tested ( 1 point for each item correctly recognized). (3) Verbal learning: the subject was given ten trials to learn a list of 10 unrelated words presented orally by the examiner (water, flower, cat, key, stone, cross, street, cake, hand, wind). His/her score was the mean of summed total recall across the ten acquisition trials. Maximal scorc of test D was 18 points. At the post-LP psychometric testing, the stimulus items of these memory tests werc substituted for other items to avoid learning effect: in test D-I were given a key and a rubber in the right hand and a pencil and a teaspoon in the left hand; and in test D- 3 were presented following words: house, ox, bread, night, bell, light, bridge, table, foot, rain.

Improvement (or deterioration) in tests $\mathrm{A}$ and $\mathrm{B}$ was defined as an increase (or decrease) of $5 \%$, and in tests $C$ and $D$ as an increase (or decrease) of $20 \%$. TT was considered as positive if the patient's performance had improved in at least one of the subtests. In the statistical analysis we used chi-square (or Fisher's exact test) for comparison of proportion; and Student's $t$ test for comparison of means between NPH patients and controls. The differences in varjables before and after shunt operation [and before and after LP (TT)] were tested by Student' $s$ test for paired data. Pearson product-moment correlation coefficient was used to determine relationships between results of TT subtests after LP and after shunting. The significance level was set at $a l p h a=0.05$.

\section{RESULTS}

NPH patients were similar to controls as regards mean age $(t=1.81$, df $=29, \mathrm{p}>0.07)$, educational level $(t=1.96, \mathrm{df}=29, \mathrm{p}>0.05)$, ventricular index $(t=0.84$, df $=29, \mathrm{p}=0.41)$, MMSE scores $(t=0.23, \mathrm{df}=29, \mathrm{p}=0.2)$, frequency of periventricular hypodensity $\left(\mathrm{X}^{2}=3.32\right.$, df $=2, \mathrm{p}=0.19)$, cortical atrophy $\left(\mathrm{X}^{2}=2.82, \mathrm{df}=2, \mathrm{p}=0.24\right)$ and dilatation of temporal horns $\left(\mathrm{X}^{2}=\right.$ $0.19, \mathrm{df}=2, \mathrm{p}=0.9$ ). Proportion of improved patients and degree of improvement at TT were higher in the NPH group ( $\mathrm{X}^{2}=9.41$, $\mathrm{df}=2, \mathrm{p}<0.01$ ). This group also had greater proportion of women (though $\mathrm{p}=0.24$ ). Among hydrocephalic patients, 5 were illiterate and 13 had at most 4 ycars elementary school. If we consider MMSE cut-off points of 13 for illiterate, 18 for subjects with 1 to 8 years education, and 26 for subjects with more than 8 years education (after Bertolucci ct al.) ${ }^{3}$, we see that all but two (illiterate) hydrocephalic patients and all but one (illiterate) controls scored below these points and showed varied degrees of cognitive deficit.

In 12 cases the cause of NPH was unknown, while in the others it was associated with subarachnoid hemorrhage (2 patients), head trauma, lacunar infarcts, cysticercotic calcifications and relapsing (biparietal) falx meningioma ( 1 each). Eight NPH patients had previously been healthy, 4 had history of hypertension, and the remaining had history of depression ( 2 patients), 
Table. Results of CSF-TT and shumting.

\begin{tabular}{|c|c|c|c|c|c|c|c|c|c|c|c|c|}
\hline Calise & $\begin{array}{l}\text { Agc } \\
(y r)\end{array}$ & Sex & $\begin{array}{l}\text { Educ } \\
\text { (yr) }\end{array}$ & Etiolngy & $\begin{array}{l}\text { First symptoms } \\
\text { [duration in months] }\end{array}$ & VI & $\mathrm{TH}$ & PVH & $\mathrm{CA}$ & MMSE & TT results: & $\begin{array}{l}\text { Effect } \\
\text { of shunt }\end{array}$ \\
\hline 1 & 62 & $M$ & 4 & Idiop. & $\mathrm{Gal}+\mathrm{Me}+\mathrm{Mi}|84|$ & 0.46 & + & $(+)$ & $(+)$ & 16 & 0 & I (A,Mi) \\
\hline 2 & 79) & $F$ & 0 & CVS & Gal $|12|$ & 0.35 & + & + & $(+)$ & 15 & (D) & I $(D, A)$ \\
\hline 3 & 64 & l: & 2 & Icliop. & $\mathrm{Gia}+\mathrm{Mi}+\mathrm{Me}|3|$ & 0.59 & + & - & - & 12 & $1(\mathrm{D})$ & $2(A, D, B, C)$ \\
\hline 4 & 71 & M & 0 & Trauma & $G_{i l}+M i+M e|6|$ & 0.37 & + & - & - & 14 & $2(D, C, A)$ & $2(A, D, C)$ \\
\hline 5 & 64 & $F$ & 0 & Cysticerti & $\mathrm{Me}+\mathrm{Gul} \mid 12\rfloor$ & 0.41 & + & & - & 7 & 0 & I $(\mathrm{C}, \mathrm{B})$ \\
\hline 6 & 65 & $M$ & 4 & Idiop. & $\mathrm{Me}>\mathrm{Mi}>\mathrm{Gal} \mid 36$ & 0.44 & + & + & - & 9 & $I(D, A)$ & $2(A, M i, D, C)$ \\
\hline 7 & $6 g$ & $M$ & 3 & Idiop. & $\mathrm{Ga}+\mathrm{Mi}|24|$ & 0.34 & - & + & $(t)$ & 14 & $1(A, D)$ & $\mathrm{I}(\mathrm{A}, \mathrm{Mi}, \mathrm{D}, \mathrm{C})$ \\
\hline 8 & 42 & $M$ & 1 & Idiop. & $\mathrm{Ga}+\mathrm{Mi}+\mathrm{MC}|5|$ & 0.41 & + & $(t)$ & - & 15 & $I(C)$ & I (MC.Mi) \\
\hline 9 & 76 & $M$ & 4 & $\mathrm{SAH}$ & $\mathrm{Gil}_{i}+\mathrm{Mi}|12|$ & 0.43 & + & $(t)$ & - & 12 & $I(D, B)$ & $I(D, B)$ \\
\hline 10 & 71 & $M$ & 4 & idiop. & Gil + Mi |12] & 0.35 & - & $(+)$ & + & 13 & $I(A, D, B)$ & I $(\mathrm{A}, \mathrm{Mi}, \mathrm{B}, \mathrm{D})$ \\
\hline 11 & 70 & $F$ & n & Idiop. & $\operatorname{Me}>(\mathrm{Gal}+\mathrm{Mi}+\mathrm{MC})|96|$ & 0.55 & + & $(+)$ & $(+)$ & 7 & 0 & 0 \\
\hline 12 & 55 & M & 4 & Idiop. & $\mathrm{Me}+\mathrm{Gel}+\mathrm{CM}|7|$ & 0.34 & - & $(+)$ & - & 17 & $1(D, C)$ & $1(\mathrm{D}, \mathrm{C})$ \\
\hline 13 & 63 & $\mathrm{M}$ & 2 & SAH & $\mathrm{Ga}+\mathrm{Mi}+\mathrm{Me}$ [180] & 0.45 & + & $(+)$ & - & 14 & $1(D, C)$ & [ (D,Mi) \\
\hline 14 & 82 & r & 3 & Idiop. & $\operatorname{Me}>(\mathrm{Gil}+\mathrm{Mi})[12]$ & 0.42 & + & - & - & 15 & $2(A, D, C, M i)$ & $2(A, M i, C, D)$ \\
\hline 15 & 57 & M & 0 & Idiop. & $\mathrm{Ga}+\mathrm{Mi}+\mathrm{MC}[3]$ & 0.41 & $(+)$ & + & - & 9 & 1 (MC.D) & $1(M C, A, D)$ \\
\hline 16 & 75 & M & 2 & Idiop. & $\mathrm{G}_{i}>(\mathrm{Mi}+\mathrm{MC})|12|$ & 0.43 & $(+)$ & + & + & 6 & $1(\mathrm{MC}, \mathrm{D})$ & $2(\mathrm{MC}, \mathrm{A}, \mathrm{Mi}, \mathrm{D})$ \\
\hline 17 & 60 & F & 2 & Idiop. & $\left.\mathrm{G}_{a}:(\mathrm{Mi}+\mathrm{mutism}) \mid 24\right\}$ & 0.43 & - & . & $(+)$ & 0 & 0 & 0 \\
\hline 18 & 75 & $M$ & 3 & Tumor & $\mathrm{Ga}+\mathrm{Mi}+\mathrm{Me}|12|$ & 0.36 & - & $(t)$ & . & 13 & (D) & 0 \\
\hline
\end{tabular}

Cntrl

\begin{tabular}{|c|c|c|c|c|c|c|c|c|c|c|c|}
\hline 1 & 77 & M & 4 & MID & Dnt+Gil+Mi |48] & 0.62 & + & - & - & 8 & 0 \\
\hline 2 & .36 & M & 4 & Alc. & $\mathrm{MC}+\mathrm{Me}|48|$ & 0.30 & - & + & + & 15 & 0 \\
\hline 3 & 70 & $M$ & 15 & Als: & $(\mathrm{i}, 1+\mathrm{Me}[60]$ & 0.41 & + & - & $(+)$ & 16 & 0 \\
\hline 4 & 50 & M & 4 & MID & DmsCVS $|.36|$ & $0.3 !$ & + & $(t)$ & + & 16 & 0 \\
\hline 5 & 61 & M & 0 & MID & $\mathrm{Gil}>(\mathrm{Mi}+\mathrm{Me})>\mathrm{C} V \mathrm{~S}|180|$ & $\mid 0.35$ & + & + & + & 11 & 0 \\
\hline 6 & 68 & M & 1 & MID & $\mathrm{CVS}>\mathrm{Ga}>(\mathrm{Mi}+\mathrm{Me})|48|$ & 0.36 & $(+)$ & + & $(+)$ & 7 & I (D) \\
\hline 7 & 51 & $M$ & 0 & MID & $\mathrm{G}: D(\mathrm{Mi}+\mathrm{Me})>\mathrm{CVS} \mid 120]$ & 10.42 & $(+)$ & + & $(+)$ & 7 & 0 \\
\hline 8 & 63 & M & 0) & $\mathrm{AD}$ & $M e>D n 1|48|$ & 0.36 & - & $\cdot$ & - & 7 & 0 \\
\hline 9 & 60 & M & 4 & MID & $\mathrm{Me}+\mathrm{G} i 1+\mathrm{annarthria}|60|$ & 0.37 & - & + & $(+)$ & 11 & 0 \\
\hline 10 & 49 & M & 5 & MID & $\mathrm{CVS}>\mathrm{G} a+\mathrm{Me}|3|$ & 0.38 & - & - & $(+)$ & 15 & $1(D)$ \\
\hline 11 & 64 & $M$ & 0 & $A D$ & $M e>(G: 1+D n 1)|60|$ & 0.34 & + & + & $\cdot$ & 9 & 0 \\
\hline 12 & 42 & $\Gamma$ & 11 & Hypothyr & $\mathrm{Gil}>(\mathrm{Mi}+\mathrm{Me})|84|$ & 0.51 & + & $(t)$ & - & 18 & $I(D, B)$ \\
\hline 13 & 78 & $\mathrm{r}$ & 11 & MII & CVS $>(G a+M e)|8|$ & 0.42 & + & + & $(t)$ & 15 & 0 \\
\hline
\end{tabular}

Cntrl, controls. Etiology: SAH, subirachnoid hemorrhagie; CVS, cerebrovascular diseatse other than SAH; AD, Alzheimer's disease; MID, multi-infirct demential; idiop., idiopithic; ale., chronic alcoholic; cysticerc., cysticercosis; hypothyr., hypothyroidism. First symptoms: Gal, gait; Me, menory; $\mathrm{Mi}$, nicturition; $\mathrm{MC}$, mental confusion; Dm, dementih; >, followed by. $\mathrm{CT}$ datti: VI, ventricular index (Evins'); TH, temporal horns; PVH, periventriculir hypodensity; CA, corticil itrophy. TT subtests: A, walking test; $B$, visto-motor speed: C. constructional praxis; $D$. memory test. MMSE, Mini-mental state exannination. In columns TH, HPV and CA: + means pronounced, $(t)$ slight, and - no, dibatation of temporal horns, periventricular hypodensity and cortical atrophy respectively. In columns for TT results and effect of shunt: 0 means no improvenrent. I fair to good improvenent ( 25 to $75 \%$ ), and 2 excellent improvenent ( $>75 \%$ or normulized). 
childhood epilepsy, theumatoid arthritis and hyperthyroidism ( 1 each). The most common neurological findings were hyperreflexia (12 patients), spastic paraparesis (6), and primitive reflexes as snouting (6), palmomental (5), Babinski sign (4), sucking (3) and grasping (2). Gait disturbance was seen in all patients, and urinary urgency or incontinence in $15(83 \%)$. Mental deterioration was detected in 17 NPH patients $(94.5 \%), 15(83 \%)$ of whom had dementia (which was mild in 6 , mild to moderate in 2 , moderate in 3 , and moderate to severe in 4), and two others had amnesia. The most frequent initial symptoms of NPH occurred concomitantly in gait, micturition and memory (5 patients), in gait and micturition (5), in gait and memory (2), only in gait (3), and only in memory (3).

Most controls (61.6\%) had vascular dementia. We found in this group a history of hypertension ( 5 paticnts, two of which had past myocardial infarct), alcoholism (3), diabetes mellitus (1), hypothyroidism (1) and hemophilia A (1).

Fifteen patients $(83 \%)$ improved after shunt surgery while $3(17 \%)$ deteriorated or remained unchanged. Improvement was fair to good in 10 and excellent in 5 patients (of whom 3 showcd normalization of gait and cognitive functions). Shunt complication (obstruction) was secn in only one patient (Case 3), which was reoperated successfully. Thirteen shunt responsive subjects had improved at TT, which showed only 1 false-positive and 2 false-negative results. Thus, there was a good correlation between the results of TT and shunt surgery $\left(X^{2}=4.11\right.$, df $=1$, phi coefficient $=0.48, p<0.05$ ). If the improvement after shunting is taken as the gold standard for the diagnosis of NPH, then the positive predictive value of our TT was $93 \%$, and its negative predictive value $50 \%$. TT sensitivity was $87 \%$ and its specificity $67 \%$.

TT subtest with highest sensitivity was that of memory (80\%), which also had high positive predictive value $(92 \%)$ [but negative predictive value of $40 \%$ ]. The symptoms most frequently improving after TT and shunt surgery were amnesia and gait disturbance, followed by visuoconstructive disability, psychomotor slowing, urinary urgency or incontinence, and mental confusion or delirium. Yet, when analysing only the patients with best improvement after shunting (paticnts 3, 4, 6, 14 and 16), we found a significant correlation between the results of the gait test after TT and after shunting $(r=0.99, \mathrm{p}=0.01)$. However, this correlation was not significant for the other subtests (test $B, r=0.52, p>0.05$; test $C, r=0$; test $D, r=0.66, p>0.05$ ). Thus, gait subtest was the best predictor of shunt results.

The search for other variables that could be related to surgical outcome (using Student's 1 test and the Fisher exact test) yielded following findings: (1) there was a tendency to less improvement, the longer the duration of NPH, even though the differences between the mean durations in 5 patients with excellent improvement (13.8 years; $S D=13.0)$, in 10 paticnts with fair to good improvement ( 35.1 years; $S D=56.1$ ), and in 3 patients with no improvement (44.0 years; $S D=45.4)$ were not statistically significant $(0.19<p<0.44)$; (2) improved patients tended to have more dilatation of temporal horns and less cortical atrophy on CT scan (though $p=0.10$ and $\mathrm{p}=0.28$, respectively); (3) unimproved patients had lower scores on MMSE $(t=2.39, \mathrm{df}=$ $16, p<0.03$ ); and (4) there was no influence of age, sex or educational level on surgical outcome and TT results.

\section{DISCUSSION}

It is widely assumed that the symptoms and signs of NPH are due to a reduction of regional cercbral blood flow ( $\mathrm{rCBF}$ ) and metabolism, as a result of a distension of third and lateral ventricles (mostly of frontal horns) related to an impairment of CSF flow ${ }^{12.21}$. Therefore, the rationalc with TT and shunt surgery has been that they lower the intracranial pressure and the need for CSF resorption, with increase of $\mathrm{rCBF}$ (mostly in the anterior periventricular white matter). The drainage of $50 \mathrm{ml} \mathrm{CSF} \mathrm{can} \mathrm{simulate} \mathrm{the} \mathrm{effects} \mathrm{of} \mathrm{the} \mathrm{definitive} \mathrm{shunt} \mathrm{surgery,} \mathrm{with} \mathrm{clinical}$ 
improvement. which, in our cxperience, lasted from $2 \mathrm{~h}$ to $48 \mathrm{~h}$. One of our paticnts improved after $24 \mathrm{~h}$ delay. Improvement with longer delay $(48 \mathrm{~h})$ and persisting many months after a single 20-30 $\mathrm{ml} \mathrm{CSF} \mathrm{tap} \mathrm{has} \mathrm{been} \mathrm{described} \mathrm{?.} \mathrm{We} \mathrm{had} \mathrm{no} \mathrm{complications} \mathrm{from} \mathrm{the} \mathrm{CSF} \mathrm{drainage} \mathrm{procedurc,}$ and the postsurgical complication rate at the 6th month and one ycar follow-up (only one case with shunt dysfunction) was lower than that reported in the literature. Shunt dysfunction may have been undetected, since the assessment of shunt patency only with digital compression is not entirely reliable.

The selection of TT subtests took into account that they had to (1) be sensitive to NPH clinical manifestations and measure cognitive functions that usually improve after LP and shunting; (2) be suited cven for illiterate subjects, on account of the high illiteracy rate of our population of paticnts ( $15 \%)$; (3) have low cost and be easy and rapid to administer by neurologists in ambulatory outpaticnts. Indeed, all patients (except Case 17) could understand and perform the tests. Case 17 had severe dementia and mutism, which precluded her to perform subtest D.3 (verbal memory). Cases $8,9,11$ and 18 could not perform walking test because of marked spastic paraparesis. Cases 6 and 16, which could only walk with significant support before LP, walked independently after it (though mildly unsteady and with difficulty for turning); after shunting, they walked almost nomally but with difliculty for turning. For these two cases, the degrec of improvement in gait was calculated on the basis of the time (and not of the number of steps) spent to walk $18 \mathrm{~m}$.

The sensilivity and positive predictive values of our TT were high, but its rate of false negatives $(11 \%)$ calls for further improvement. The patients who did not improve after TT and shunting probably had irreversible structural changes, as much as can be inferred from their low MMSE scorcs and marked dementia. Patient 18 did not improve probably because his moderate hydrocephalic dementia was associated with a small, slowly growing (recurrent) falx meningioma, which could have led to impairment of CSF resorption and possibly also to dystunction of neighboring associative pariclal cortices al bolh sides. Patient 17, with mutism, showed improvement of speech production during the first postsurgical month (she could give answers with appropriate words and short sentences). but then returned to her previous state.

In agrecment with the literature ${ }^{11,13,24}$, we have found that short history, gait disturbance preceding mental deterioration, as well as wide temporal horns and small sulci (but not periventricular hypodensity) on CT scan werc associated with good outcome after shunting. Long duration of dementia (and low MMSE scores) tended to correlate with poor outcome. On the other hand, in contrast to several other studies ${ }^{13.24}$, we could not confirm knowing of the causc as a prognostic lavourable factor: The degree of improvement in the group with NPH of known cause was the samc as in the idiopathic group (80\%). Nevertheless, this does not allow us to question the prognostic relevance of etiology, since in some of our cases the low educational level and the lack of medical records of their past history may help to explain the unknown etiology.

Overall, our findings contirm those of Wikkelso et al. ${ }^{24}$ pointing to the high diagnostic and predictive valuc of TT, particularly in situations where the clinical and CT data are inconclusive and do not allow to lake the decision to operate or not. We think that TT should be further improved, cspecially by developing more specific tests for NPH disturbances of gait. posture, micturition and cognition, as well as by increasing the amount of CSF removed, preferably by means of one day's repeated or continuous CSF tap (which would reduce the risks, troubles and costs of the live day's continuous external drainage proposed by others).

Acknowledgements - This work was supported in part by a grant to the first author liom FAEP (Fundo de Apoio ao Ensino e i Pesquisa) at Medical School, Campinas University. The authors are grateful to Dr. Fernando Cendes and Dr. Iscia Lopes Cendes (Montreal Neurological Institute) for their critical review and stylistic contributions, as well as to the medical residents at the Department of Neurology for their help in the handling of the patients. 


\section{REFERENCES}

1. Adams RD. Fisher CM. Hakim S. Ojentann RG, Sweet WH. Symptomatic occult hydrocephalus with "normall" cerehrospinal t]uid pressure: a treatiable syndrome. N Engl J Med 1965;273:117-126.

2. Bergstrand G. Oxenstierna G, Flyckt L, Larsson SA, Sedvall G. Radionuclide cisternography and computed tomography in 30 healthy voluntecrs. Neuroridiology 1986:28:154-160.

3. Bertolucci PHF Brucki SMD, Cimpacei SR, Juliano Y - O mini-exime do estado mental em uma populaçío geral: impácto da Lxcolitridacle. Arc Neuropsiquiatr 1994;52: I-7.

4. Chen IH, Huang CI. Liu HC. Chen KK. Effectiveness of shunting in patients with normal pressure hydroceplaalus predicted by anporaty, contoniled-1csistance, continuous lumbar drainage: a pilot study. J Neurol Neurosurg P'sychiatry 1994:57:1430-1432.

5. Christensen A-I. I uria's neuropsyclsological investigation. Ed 2. Copentiagen: Munksyaird. 1979.

6. Di Liluro L. Mearini M. Botalli A. The predictive value of S dalys' CSF diversion for shunting in nomial pressure hydrocephulus. J Neurol Neurosury Psychiatry 1986:49:842-843.

7. Fisleer CM. Communiciting lyydrocephalus, Lancet 1978; Jan 7:37.

8. Fisher CM. Hydrocephalus as a ciuse of disturbances of gait in the elderly. Neurology 1982:32:1 358- 1363 .

9. Folstein MF. Folstein SE, McHugh PR. Mini-mental state: a pratical method for grading the cognitive state of patients for the clinician. I Psychiatr Res 1975:12:189-198.

10. Ganmabattcriet (Gamma-bittery) Manual. Stockholm: Pkykologiforlatget AB, 1976.

11. Graff-Radford NR, Godersky IC. Normal-pressuce hydrocephalus: onset of gait abnormality be fore domentia predicts good surgicil outcome. Arch Neurol 1986:43:940-942.

12. Grafl'-Riddford NR, Rezai K, Godersky JC, Eslinger P, Damuasio H, Kirchner Pr. Regional cerebral blool flow in nomal pressure hydrocephialus. I Neurol Neurosurg Psychiatry 1987;50:1589-96.

13. Larsson $\Lambda$, Wikkelso $C$, Bilting $M$, Stephensen H. Clinical partimeters in 74 consecutive patients shunt operated for normal pressure liydroccphalus. Acta Neurol Scind 1991:84:475-482.

14. McKahnn G. Drachman D, Folstein M, Katzmen R, Price D, Stadlan EM. Clinical diagnosis of Alzheinter's diseise: teport ol' the NINCDS-ADRDA Work Group uncler the auspices of Depatment of Health and Hunam Services Task Force on Alzlkeiner's diseisc. Neurology 1984:34:939-944.

15. Reisterg B. Fertis SH. De Leon MI, Crook T. The Global Deterioration Sciale for assessment of priniary degenerative denential. Am J Psychiatry 1982:139:1136-1139.

16. Ross I:IJ. Sensory-specitic and fractional disorders of recent memory in man: II. Unilateral loss of lactile recent memory. Arch Neurol 1980:37:267-372.

17. Strub RL. Black FW. The meutal state examination in neurology. Philadelphia: F.A. Davis, 1977

18. Vannesie I. Three decades of normal pressure hydrocephalus: are we wiser now? (editorial) J Neurol Neurosurg Psychiatry 1994:57:1021-1025.

19. Vanneste J. valu Acker R. Nomal pressure hydrocephalus: did publications alter management'? J Neurol Neurosurg Psychiatry $1990: 53: 56+568$.

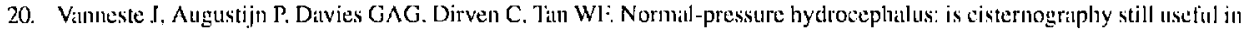
selecting pitients for al shunt? Arch Neurol 1992; 49:366-370.

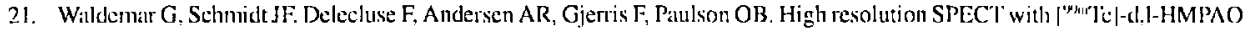
in normul pressure hydrocephalus before and after shunt operation. J Neurol Neurasurg Psychisitry 1 993; 56:65.5-664.

22. WHO. Mental behavioral ind developmental disorders. In International Statistical Classsification of IDiseares. IOtl Revision (ICD-10). Gencvil: World Heallh Organization; 1992: chap 5. Categories F00-F99.

23. Wikkelso $\mathrm{C}$. Andersson $\mathrm{H}$, B lomstrand $\mathrm{C}$, Lindqvist $\mathrm{G}$. The clinical effect of lumbar puncture in normial pressure hydrocephal I Neurol Neurosurg Psychiatiy 1982: 45:64-69.

24. Wikkelso C. Andersson H. Blonstrand C, Lindqvist G \& Svendsen P. Normal pressure hydrocephalus: predictive value of ulhe cerebrospinal fuicl tap-test. Acta Neurol Scand 1986:73:566-573. 